\title{
New Sites/Sights: Exploring the White Spaces of Organization
}

\section{Damian O'Doherty}

University of Manchester, UK

\section{De Cock}

University of Essex, UK

\author{
A Rehn \\ Åbo Akademi University, Finland
}

\section{K L Ashcraft}

University of Colorado, Boulder, USA

\begin{abstract}
In this introduction we seek to establish and position the distinctiveness of our approach to what we claim to be 'white spaces' in organization, an approach that compels a significant breaching of the disciplinary norms of organization studies. We derive our argument from a consideration of a range of recently emerging concepts and analyses in the study of organization, all of which are suggestive of crisis and of emerging (anti-)forms of organization. Contemporary organization is increasingly understood as contingent and improvisational - and immersed in complex and shadowy realities where customary assumptions about the space and time of organization no longer hold. This special issue invites organization studies into an ambivalent space of sites/sights in organization, the double-play of this modest conceptual proposal necessary in order to open up the complex folding of the epistemological and ontological in organization today. This edition of Organization Studies publishes six papers that advance this emerging problematic in organization and in their various ways extend our understanding of possible organizing futures.
\end{abstract}

\section{Keywords}

New Organization Theory; Crisis; Para-sites; White-Spaces; Interdisciplinarity 


\section{New Sites/Sights: Exploring the White Spaces of Organization}

\section{Introduction}

There is a sense of foreboding and crisis in the field of organization studies. Formed out of a relatively stable post-1945 western political economy and built on the at times uneasy alliance of social democracy and neo-liberal free-market economics, organization studies has by and large enjoyed a remarkable period of growth. Its institutionalization as an academic discipline has meant that it has been relatively insulated from the series of more recent events suggestive of seismic shifts in the nature and form of "global capitalism". In this respect the apocalyptic tone increasingly adopted amongst climate specialists (Leahy et al., 2010), the Arab Spring challenge to the existing North-South balance of power in the middle-east, the global discourse organizing a Manichaean-like 'clash of civilizations', networked terror, and the anarchic consequences of the end of US Empire, offer evidence of game-changing events (cf. Clegg and Courpasson, 2007). On another scale bacterial and chemical 'wars' viral pandemics, biogenetic deformation and cross-species mutations provide additional resource for those seeking to advance a crisis narrative (Cockerham \& Cockerham, 2010).

For some these changes are so significant that they cast doubt on the legitimacy and longevity of western democracies (Mitchell, 2011) - and by implication this casts doubt on the future of the social and applied social sciences. The fate of the social sciences, given recent challenges to the modern nation state, is certainly one that has been implicit in certain papers in organization studies addressing the (once?) fashionable work of Foucault, Derrida, Kristeva and Lyotard (and more recently Deleuze and Guattari, Irigaray, and Žižek - and on the horizon we see Badiou, Meillassoux and Rancière ripe for translation into our discipline), but it is notable that there is a signal lack of work on the implications this writing has for the disciplinary norms, boundaries and research and writing practices associated with organization studiesii. Foucault (2003) was explicit in stating that the modern social sciences are complexly both cause and consequence of the rise to power of the modern European state system and if, as his genealogy hints, this history can be written, it is because we are now arguably approaching its end(s). Of course, in order to establish such an epochal claim this writing must affect a breaching of existing modern disciplinary knowledge practices. In this respect there can be no doubt Foucault was writing peculiar forms of (anti-)disciplinary narrative that he variously called archaeologies, genealogies, and 'fictions' that 'fabricate something which does not yet exist' (Foucault, 1980:193). 
The field of organization studies has by and large evaded these larger questions and therefore remains blind - and perhaps constitutively so - to what we are here calling the emerging 'white spaces' of organization, and this despite the fact that new social and economic relations are being forged in and around these sites/sights (Boltanski and Chiapello, 2005). The failure to respond meaningfully to the 2008 global financial crisis (Morgan et al., 2011; De Cock et al., 2012) is suggestive of this blindness, for example, and the lack of public policy impact is arguably an indictment of the perceived relevance and seriousness of analysis offered by specialists in organization studies. Organization studies is not alone in this respect but perhaps Graeber's (2013) recent polemic offers one noteworthy exception where he offers a systematic and rigorous response to the political and systemic consequences of the post-Lehman financial world. However, whilst creative and imaginative, and undoubtedly ambitious as an intervention, the activist and muscular tone adopted in such works will sound shrill to many in organization studies. Indeed, with its jeremiadic and grandiose tone, Graeber's work could be seen as much as a symptom of crisis as it is a radical diagnosis or 'solution' that avoids the reproduction and advance of dominant discourse. This is also the failure, perhaps, of those approaches in post-colonial organization theory and climate change analyses that seek relevance through the advance of a critical management studies (e.g. Banerjee, 2011; Böhm; Misoczky \& Moog, 2012).

Instead of this confrontational and head-on approach - which risks producing and reproducing precisely that which is most feared - we might therefore seek to advance an approach that circumvents a dialectic of opposition and recuperation. We might do this by attending to those forces and relations in organization that generate everything which is tangential and aberrant to the organizational dualisms of centre-margin, power-resistance, structure-agent, etc. Such breaching activity does not happen of course without a certain commitment to conceptual innovation that can extract and cultivate that which is nascent, half-formed, always in movement and changing. And yet, as Robert Cooper (1998: 128) once wrote, "we are not good at thinking movement", in part because this movement disrupts and unsettles our customary categories and classifications.

This special issue thereby invites organization studies into an ambivalent space of sites/sights in organization: the 'double-play' of this aural homonym and modest conceptual proposal necessary in order to signal and encourage work that improves our capacity to engage with this movement- in-organization. On first reflection it might be said that sites/sights can be seen, but not heard. However, listening to the spoken word does not permit an easy classification or simple sense-making: sight or site? This conflation and confusion is deliberate. Further consideration might remind us that there is a relation 
between sight and sound in the sense that we are stimulated to re-view that which we think we hear. A 'site' is dependent of course upon 'sight', and vice-versa. We always necessarily see from somewhere, or from someplace (whether theoretically, politically, methodologically) to another place. But unlike in the modern Kantian settlement, sight is more fruitfully understood not as passive but rather active (Levin, 1988) - which in its turn re-animates site in a circulating relation, albeit potentially invoking a regressus ad infinitum. If methods are metaphors (Cunliffe, 2011; Hatch and Yanow, 2008; Morgan, 1983), and a metaphor etymologically is transport, then working through sites/sights in organization might help find ways of recovering movement in the 'Cooperian' sense. If we were simply attuned to the sense of hearing, or to the separation of sight and sound we might miss this ambivalence and movement. We are not privileged as theoretical subjects in tackling this ambivalence; we must assume that this aporia plays out in practical acts of organization.

In developing organization studies beyond its current impasse we might therefore need to allow some 're-tuning' of our all-too-human sensory apparatus (see Ulmer, 1985). This retuning, however, is likely to stimulate a heightened awareness of movement-in-organization that might produce an experience of synaesthesia (O'Doherty, 2008). Despite its creative possibilities, the modern social sciences remain constitutively resistant to this form of theorising. One mythic victim of this resistance to the synaesthetic imagination was of course Zarathustra who was heard to exclaim: 'Must one first batter their ears, that they may learn to hear with their eyes?'(Nietzsche, 1891 [1961]: sec.5). Our contributors to this special issue do not seek to 'batter' your ears, but we suspect the discipline will find their papers challenging as in this double-play of sight and sound different forms of writing emerge. Before introducing the papers we first seek to establish and position the distinctiveness of our approach to what we claim to be the 'white spaces' in organization.

\section{Beyond the network: Space and time out of joint}

A number of concepts and preferred forms of re-thinking organization have been suggested in an effort to recover the ground lost in the wake of our varied crises. Some have proposed the idea that the dominant mode of organization is now 'networked' (Castells, 1996). From DNA to viral marketing, the concept of networks has been undoubtedly fertile in drawing analogies across organization - at different scales and in different materials. This popular rendering of network organization, however, makes too realist a claim to ontology and one that is insufficiently subtle to engage with what we are calling new sites/sights in organization. Both simplistic and reductive in its realist claims, the concept of 'networks' lacks a degree of precision and tends to be used to characterize anything that appears other 
to the bureaucratic and closed, internally referential figure of organization in modern organization theory. It has thus become a defanged concept, made insidious through its circulation in a range of celebratory and 'boosterist' discourses promoting the virtues of neoliberal global capitalismiii.

More compelling are those concepts that identify a new permanent 'state of exception' evident in the rise of 'the camp' as a dominant form of contemporary organization (Agamben, 2005). At first, the camp is other to the nation state, its polar opposite or 'supplementary' condition of possibility. However, what Agamben does with this concept is to use the term to displace such an opposition so that we might begin to see the state as a version of the camp; a camp that has forgotten its temporary and transient nature. Hence, the relational qualities of space opened up by Agamben disorient our sense of territory and space in a useful manner, and in so doing releases more complex geographies to allow us to make connections across phenomena otherwise made invisible.

A related spatio-temporal challenge is posed by the proliferation of 'rogue states' (Elden, 2009), 'para-states' and 'para-military' activities that are clearly organizational in nature, but without fixed location or time. In other words, they are 'outside' of the state form, or accountable forms of regulation and control. Their 'organization' has to be traced, instead, as a complex relationality of implications and associations that does not observe bureaucratic and other inscriptive modes of management and accountability. In these forms of organization, lines of command and control are not stable but dispersed, distributed, and transient. In addition, the significance of their organization cannot be restricted to any bounded entity such as a business firm or limited liability company.

Of course, alternative modes of organizing have long shaped the interstices of western economic, political, and social life - feminist practices to counter bureaucratic impulses, for example, and other experiments in social movements, collectives and activism (e.g., Ferree and Martin, 1995). Rarely acknowledged by management and organization scholarship, these forms of organization represent important efforts to challenge a functionalist orthodoxy. However, whilst such efforts defy and rework dominant relations of coordination and control, they also retain a historical commitment to organization as a coordinating and functional entity that exists in the form of a bounded and essentially realist form. On the one hand they pose an important challenge to bureaucratic tyrannies in their quest for enabling other intelligible forms of governance, but on the other they are still anchored in conventional understandings of place and time. This special issue collects papers in organization studies that seek to develop an approach that is more sensitive to amorphous and elusive 
formations of 'resistance' to the mainstream and simplistic empirical realism. Indeed, the fact that the management literature can readily subsume such alternatives as 'post-bureaucratic' or even 'postmodern' technologies of competitive advantage (Ashcraft, 2001), thereby sanitizing moral-political claims and arresting the promise of deeper confrontation, is suggestive of the high price of admission as 'an organization'. Crucially, then, the 'organizations' of which we speak move beyond the static nodes and relations of the network metaphor. They are in important ways 'space-making' and, whilst operating in complex temporalities, are also constructive of time.

By contrast, studies of the international arms trade (Stohl and Grillot, 2009), Latin American drug wars (Watt and Zepada, 2012), child sex-abuse, prostitution, or other forms of 'human trafficking' (Kara, 2009) clearly open up difficult and uncharted spaces and times of organization. Difficult to access, and operating in subterranean and 'shadowy realities', organization almost disappears as an object of scrutiny, analysis and operation. That these kinds of studies have been conducted outside of organization studies is also notable. Those who have begun to research these 'global industries' find complex spatialities and temporalities - created, for example, when a criminal underworld meets the underbelly of formal state institutions (Saviano, 2008). Territory becomes interstitial or inter-national in that old sense evoked by the maritime custom of mare liberum in which a void opens up between different national legal systems and state regulations in order to facilitate international trade. In terms of temporalities we are not primarily thinking here of the extraordinary time-coping strategies of prisoners or the 'double-agents' that operate in this shadowy world (e.g. Keenan, 1993; Scarry, 1985), useful though this might be to understanding white spaces, but rather how, similar to space, time also escapes customary forms of regulation. This poses a far greater challenge to organization.

Beyond the customary opposition of the subjective and objective we might characterize this as a form of 'time' in organization that is not 'human time' and better thought perhaps in those terms offered in Derrida (1994) where he refers to the Shakespearean form of 'time out of joint'. The existence of organizational 'change' is a truth universally acknowledged in our discipline, but if we were to get rid of the fiction of 'stasis', of change occurring between two fixed points in time, then we must also find a new language to conceive of change. In the absence of its oppositional term, the concept of 'change' of course no longer makes much sense. This 'time-out-of-joint' offers a useful way of conceiving movement in organization, one marked by the collapse of habitual temporal coordinates and one that raises the prospects of a kind of ex-stasis. In its twilight world we find this ex-stasis confuse legal and illegal boundaries that remain almost sacred to the self-representations that liberal 
democracy offers to itself. From Abu Ghraib to Guantanamo Bay; from drone strikes and extraordinary rendition flights to private armies and the US Patriot Act; it seems we now live in a world that is being organized beyond the categories and concepts that organization studies has inherited from the modern social sciences. Hence, we propose the concept of 'para-sites' as an initial marker to help put some shape around these emerging white spaces in organization.

\section{Organizational para-sites and the 'event' in organization}

We are beginning to see that organization does not exist in space and time. However, we have also noted that organization studies is not good at thinking 'movement', especially when we lose the coordinates in which movement has been traditionally thought, relegated to a secondary or derivative process that is confined between two endpoints. It is particularly ill disposed to study the kind of movement that is associated with these para-state and paramilitary forms of organization. In part this is because the social sciences remain what Deleuze and Guattari (1988) call 'state forms of thinking'. Here of course the word state evokes 'static', which is also etymologically tied to 'statistics' - another form of knowledge practice constitutive of the modern nation state (Hacking, 1990; Rose and Miller, 1992). In other words, we are too static in our thinking, but also too static in the divisions we make between thinking and acting, or thinking and being. The white spaces of organization to which we want to take the reader do not submit to established forms of thinking, but rather demand a more experiential, practical and engaged craft of research practice. To use Badiou's (2005: 46) vocabulary, they demand a sensitivity and openness to the 'truth of the event':

"For the process of truth to begin, something must happen. What there already is the situation of knowledge as such - generates nothing other than repetition. For a truth to affirm its newness, there must be a supplement. It is unpredictable, incalculable. It is beyond what is. A truth thus appears, in its newness, because an eventual supplement interrupts repetition".

Thinking, then, is itself derivative or secondary to the more primary processes of 'the event'. White spaces are not objects to which thought can turn our eyes, nor in this respect 'sites', but as we shall see, something both more and less - sites/sights. The papers published in this special issue show that 'white spaces' do not simply await their discovery; they require an openness and retuning of the scholarly apparatus that allows these 'white spaces' to rise above the horizon of social invisibility. And yet, particularly when defined as 'business and 
management' scholars, we have been reluctant to grant earnest consideration to the complex topography of organizing practices - perhaps because these practices pose a considerable challenge to our customary modes of research and the productivity achieved by these habits and conventions. In part this explains why the discipline of organization studies continues with 'business as usual', despite what has been recognized by an increasing numbers of scholars as a shifting (or even dissolution through attrition) of the tectonic plates that have undergirded the modern social sciences (Foucault, 1970). Organization studies has in the main continued to advance an agenda within terms acceptable to the contemporary business school with its focus on an abstract and rationaltechnical curriculum. The stable diet continues to be made up of issues such as 'organizational development', 'mergers and acquisitions', 'corporate strategy', 'leadership skills', 'organizational behaviour' and 'motivation'.

On one level this is understandable. Tracing the forms of organization that might help explain something so complex as the Arab Spring is a daunting prospect, even if we were inclined to make this the object of our analysis. There are also few who desire (or, indeed, have the capacity) to venture into the blurred boundary lines between the legitimate and illegitimate (Rehn 2008), or into the business practices associated with an increasingly globalized crime industry (cf. Parker, 2011). One can also understand why academics might shy away from exposing the full network of relations involved in such practices, especially where the collusion and complicity of the institutions of the liberal state form begin to appear systemic and not simply the anomalous 'mistakes' of corrupt or rogue agents. Indeed these are times in which the very publishers with whom we place our work, and the universities at which we are employed, have become complicit (Beverungen et al., 2012).

\section{The perennial question: What is organization?}

The millenarian discourse of crisis with which we began is suggestive then not so much of new sites of organization that are fixed in spatial location or measurable in terms of regular temporal scales, but of rather more shifting and protean forms of organizing. It has become a truism to affirm that organization does not inhabit a discrete location (Chia, 1995) and that it does not limit itself to the idiomatic 'nine to five' of which Dolly Parton famously sang. The organization of crisis which we are seeking to delineate here clearly escapes these coordinates and is formed out of associations and relations that extend across a series of apparently discrete academic subject areas - political science, climate science, sociology, economics, psychology, etc. When carved up into these distinctive forms of expertise, it is difficult to see the possible forms of organization that cut across these divisions and hold it together. However, if there is one form of expertise we can claim, it is this claim to 
'organization' - and with this rather weak concept we are perhaps able to trace something that is prior to the disciplinary bureaucratization in which we are both subject and object.

Organization is a flexible term, both morally and ontologically. It covers objects as disparate as a bus queue and 'neo-liberal capital'. However, we rarely think at the scale of large systems, of what is called 'capitalism' or 'democracy' (Prichard and Mir, 2010). Nor do we conduct our investigations at the molecular level. Instead we adopt a mid-range perspective that takes the most familiar and reified objects and categories of analysis, much of it distilled from the practitioner language of business and management, and declare this to be 'organization'. Enduring and recent efforts to problematize this manoeuvre and renew the question of what is organization tend to zoom in on the meso-level - theories of the firm, for example, or some explanations regarding the communicative constitution of organization. Whilst the middle range may merit investigation, we do well to also treat our fixation upon it as odd and unnatural, perverse even, and exhort organization studies to stretch beyond this zone of comfort. Yet we rarely do so.

This becomes doubly strange if we are to take seriously the repeated demands made upon us to adopt a 'pragmatic approach'. For organization studies is one of the few subject disciplines in a business school that is not allied to a professional or occupational practice in business and management such as 'accounting and finance', 'marketing', 'human resource management', or 'operations management'. It does not take a great deal of ethnographic research to come to the realization that no one is responsible for this thing called 'organization' in the world of business management. Without such location in the world of the practitioner we cannot offer a professional qualification in organization studies. No one is appointed as 'head of organization'.

So, organization remains an odd subject: intangible and meta-analytic, both verb and noun, as has been well studied in general theory since at least Weick (1979) and developed in a number of recent genres, including 'process philosophy' and the practice-based turn in strategy analysis. It is also without the fidelity of social scientific discipline, emerging as it did from a variety of fields of study and within distinctive and somewhat paradigmatically incommensurable European and North American genealogies (Jackson \& Carter, 1991; Burrell, 1996; March, 2007). Without practice, therefore, bereft of object and without subject, organization studies might very well appear to be in a parlous state. Yet this situation might also be its very fortune and reprieve. Foucault's genealogies of the modern social sciences is suggestive in this respect, showing how the social sciences were dependent upon a unique set of historical conditions tying together emerging modern institutions with particular 
discourse-practices that helped express and give form to the emerging modern European states system (Foucault, 2008). It might be a little ironic that the social sciences have found 'issue' in this 'site' we call organization studies, but it does suggest that we might be well placed to imagine the resources that may be required to explore the interstices and 'transversal' connections that take us somewhere outside the established practices of the social sciences. Crisis always represents opportunity and it speaks of a turning point, although we can never be clear whether the turn is a sign of health or degeneracy. Ultimately it is up to us as organizational scholars to inflect the 'evental' nature of crisis in positive or negative directions according to the demands of circumstance and strategy.

It is with these concerns in mind that we posed our question about new sites/sights in organization. As we have suggested, this aural de-differentiation alerts us to the complex relationality and movements involved in rendering visible those sites of organization we wish to address. These movements remain basic and embodied in the sense that the primal act of 'seeing' is only possible in the flow of motion: at the most fundamental level seeing is the movement of light, or in Bergson's terms, of one movement-image striking and interacting with another movement-image, objective exteriority and subjective interiority collapsing into a more intensive materiality in which the body becomes both a complex medium and image processor (Bergson, 1911). We have argued that seeing is a material and practical activity and we adopt this principle in order to 'follow the actors' (Latour, 2005) who are themselves reflexively involved in the practical activity of making sights/sites. Reflexivity cannot be assumed to be the privilege of the heroic academic (Lynch, 2000), and it is always a good idea, Latour reminds us, to remember that as researchers we are always one-step behind the reflexive practices of those actors whom we are studying in their making of organization.

\section{Terra incognita}

Used originally by Ptolemy to designate a great southern landmass that connected Africa with South-East Asia, terra incognita was that part of the world not-known, or variously unexplored, inaccessible, even unknowable. There is an important history of empire associated with this mapping of 'white spaces' (Hobsbawm, 2011) into which missionaries, intrepid adventurers, anthropologists, and the military sought new experiences, plunder and conquest. Over the centuries the shape of this terra incognita has variously shifted and morphed, from Mercator and Ortelius up to the recent maps of situationist and psychogeographic practices where it has assumed all manner of fantastical projections (Pinder, 2005; Sadler, 1999). White spaces are important because they offer an Other into which we often project our deepest fears and fantasies and thereby offering resource upon which to 
reflect and take measure of the community from which the venture out proceeded. However, they also served as a target against which to muster the resources of 'enlightenment' power - and this is a danger to which we must remain attentive. Hence the creation of white spaces in situationist cartographies was precisely designed to provoke a political challenge to existing claims to knowledge and to impart uncertainty and humility into the arrogance of the rational and objectivist 'juggernaut of modernity' (Giddens, 1990).

White spaces as cartographic projections also marked the boundaries of western imperial ambition and the limits of order and reason. This provenance should inspire us in developing our own notion of white spaces in organization because we cannot ignore the implications that white spaces pose to established understandings of power in organization studies (Clegg, Courpasson \& Phillips, 2006). Power always seeks out its resistance and so its study must expect to be confronted with all kinds of paradoxes and double-binds through which social relations and organization gets stabilised. In marking out the limits of power and its organizational and institutional configurations white spaces - to risk standard linear thinking for the moment - also help delineate where the action is going to be focused in the future.

If Pliny provided the resources to imagine the kinds of fabulous beasts that might populate terra incognita in classical antiquity - from the centaurs and griffins, to the sphinx, mandrakes and pelicans of popular imagination (Murray, 2005) - we think it important to consider their equivalents in more recent times and to consider those non-human actors that might be dismissed or deemed irrelevant because of their 'fantastical' qualities. In these ways we extend the work of others who have found ways of treating 'monsters' in organization (Law, 1991; Thanem, 2009). Where recent advances in cartography have called into question the very divide between the fantastical and objective (Cosgrove, 2008; Crampton, 2009; Wood \& Fels, 2008) ' $^{\text {iv }}$, it is likely that our contemporary 'fabulous beasts' will offer similarly fantastic tales, but now from the world of hybrid techno-sciences, teletechnology and multimedia (Han, 2008; Turkle, 1995; Weber, 1996). Indeed, it is rather revealing that another mythical 'fabulous beast', the chimera, has now become a standard term in genetics to describe a single organism that is composed of two or more different populations of genetically distinct cells. In doing so, however, and in studying action beyond that reserved exclusively for the human agent, we necessarily open and engage in a disruption of the established distribution and processes of power in organization, something to which most colleagues in organization studies shy clear.

The papers which follow are abound with all manner of possible fantastical 'non-human' actors: audio-visual doppelgangers (Beyes and Steyaert), 'sticky' non-places (Costas), the 
materials that facilitate child's play (Kavanagh), buildings that 'speak' (Hirst and Humphreys), the colour-effect of 'white' (Connellan), textiles and quilts which appear to have been offered as a kind of 'sacrifice' to organizations and their chief executive officers (Rippin) (cf. Taussig, 1992). By putting into play these fantastical non-human actors we mark out new sites/sights that cannot be classified as the inherent violence, disease, crime, or corruption in organization - these would be best considered as candidates for what has recently been called 'the dark side of organization' (Linstead et al., forthcoming). Instead, the sites/sights we want to explore occupy more difficult temporal and spatial dimensions of organizing and in important ways, as we shall see, they remain on the boundary of the knowable. Whilst there may very well not be sufficient interest in the organization of war, violence and crime (Clegg, 2006), our interest lies in the moral, epistemological and ontological confusion that attends the disclosure of the white spaces of organization. In calling our discipline 'ignorant' Clegg issues a strong condemnation of organization studies that speaks from the certainty of a powerful moral standpoint which we think cannot be justified when treating these specific white spaces.

\section{Uncanny Beasts: Introducing the papers}

None are more reflexive perhaps than the insane documentary practices of former totalitarian state regimes. In Beyes and Steyaert's (2013) paper we are taken into the methodology of an audio-visual technologically extended 'situationist derive' (Debord, 1958) that opens up the repressed violence and histories buried in the city of Berlin, and which continue to haunt the organization of an apparently unified Germany. This makes organization, in their words, 'uncanny'. The authors take us into the dark heart of the modern European project and recover the hallucinatory reality of the former East Berlin secret police, traces of which are still active as organization today. Their research is a kind of pararesearch in that they are invited to make themselves parasites upon the research practices of the experimental theatre group Rimini Protokoll, who are themselves studying the 'studies' of the former Stasi. Recalling the practices of the 1960s 'happenings' (Kaprow, 1965), the theatre production helps mobilize its audience as actors, who take to the streets of Berlin to participate in an emergent and collective script that helps recover memories and associations latent in the city. The actor is invited to experience what we have called 'timeout-of-joint' as they are turned into audio-visual 'mediums' or mediators that brings about the collapse of the different temporal layers of the city. By becoming actors and writers in an open theatre production, the streets of Berlin become new sites/sights of organization offering powerful insights into an almost visionary reality of how we are organized by cities and their underlying paranoid logic of militarized encampment and its permanent war footing (cf. Graham, 2010). 
By contrast Costas (2013) focuses on the apparently glamorous world of international management consultancy. She shows how the neo-liberal celebration of the 'mobilities' generated by global capitalism are undercut by a series of what she calls 'ambiguities' and 'contradictions' experienced by the very kinetic elite who are supposedly its beneficiaries. Instead of fluidity and the 'flows of space' that Castells (1996) evokes, Costas explores the proliferation of 'non-places' as introduced by the writings of Augé (1995). Here she finds the sense of 'stickiness' and the paradoxical qualities associated with the experience of 'fixed instability' and permanence together with ephemerality. Non-places always promise to take you elsewhere; they produce confinement but also the sense of liberation, of a temporary emancipation from the mundane world of routine and ritual, whilst being at the same time widely reported as vapid and tedious. Like the 'uncanny' in Beyes and Steyaert (2013), these non-places are disturbing and disruptive, void of community or sociality. The anonymity generated by places such as airports, train stations, supermarkets, and suburban housing estates, is also dangerous, providing fertile grounds for calculated but also random acts of violence and atrocity (see Ballard, 2003). Gateways to the very mobilities that neo-liberal capitalism promises they also mark out some of its limit conditions.

Media and outcome of dis-organizational or entropic forces, the non-place induces disconnection and alienation. As one of Costas's respondents tells her, the experience of passing through these places is like being 'stuck on a project in the middle of nowhere.' These spaces offer new sites/sights in organization that are constitutive of new forms of experience and subjectivity and through our use of them as tools of research we can cultivate 'ways of seeing' that are attentive to the new lines of flight and entrapment that traverse contemporary organization. How close we come to reproducing the phenomena we are putatively studying, so that academic endeavour becomes a global industry marked by the same travel, displacement and alienation experienced by our research subjects, is a point worth considering. The extent to which we project into our field sites our own fears and fantasies of global capitalism raises profound questions about tautology in knowledge production (Cooper, 1983). What is without doubt is that in these non-places many individuals are quickly enrolled into descriptions of their experience that express being disorientated and lost, of being 'dissolved' or 'taken over'. In reading this paper we begin to share with Costas the sense that this kinetic elite is circulating around a contemporary version of one of Dante's circles of hell. Yet, as symbols of the global power of capital, they are also sites for the emergence of what Latour (2005) calls 'plasma' or an excess of potentiality (or in Deleuzian discourse: 'virtuality') in which we might glimpse new ways of being and world-making, many of which, of course, we might wish to curtail. 
One site of an 'excess of potentiality' might be found in children, who also represent a major absence, a terra incognita of age, in organization studies. Using Spivak's postcolonial writings on the subaltern and actor-network theory as sensemaking and structuring devices, Kavanagh (2013) explores how organization studies can gain from the engagement with children and childhood. He proposes six research trajectories - epistemological, ontological, methodological, temporal, political, and reflexive - to frame this engagement and map out a research agenda. Yet, Kavanagh is also wary of mapping out this particular 'white space' of children. In a Foucauldian reflection on the entanglement of knowledge and power he realises that in presenting knowledge of children, "by seeking to place them in organization studies", there exists "a real danger of doing (collateral) damage to the idea of childhood". We are reminded here of Coetzee's (1988) reflection on 'white writing'; the way South Africa as landscape and landed property has been thought by Europe. In the first chapter of White Writing Coetzee considers the representations of idleness (another significant white space of organization studies) of the Hottentot in colonial writings and its subsequent revisiting in postcolonial discourse. He warns: "In the very open-mindedness we might like to imagine extending toward the Hottentot from the modern science of Man lies the germ of an insidious betrayal of the Hottentot (p.35)". Coetzee continues, "it would be particularly rash to expect the modern researcher... to respond more generously than his ancestors to a way of life so indolent that, in its extreme form, it presented him with nothing to say." This then is the danger and paradox of exploring white spaces. If we are to revitalise our field and challenge its basic assumptions we must venture into the white spaces of organizing; but in behaving like $19^{\text {th }}$ century intrepid adventurers we may fail to see that some things should perhaps properly remain opaque to us: Spatially and historically distant, intractable and even misunderstood, and therefore somehow 'safe'.

Like Kavenagh, Hirst and Humphreys (2013) are inspired by the repertoire of ideas provided by actor-network theory (they call theirs an ANT'ish study, and perhaps the study of new sites/sights requires the not-quite-fixed methodologies of '-ish'). They describe how an architecturally state-of-the-art $\mathrm{HQ}$ becomes a macro-actor enabling senior managers "to redefine themselves as mobile, flexible and active". We can imagine these managers working easily alongside Costas's kinetic elite. Yet, it is when Hirst and Humphreys' attention moves from the shiny centre of the $\mathrm{HQ}$ to the periphery of the records management office - "welcome to the shithole" an employee says to the researcher - that the study truly gets into the edgelands of organizing. Surrounded by wasteland and a sewage works, this is a site that is organizationally marginal, disdained even, and yet it provides us with tantalising glimpses into the crucial centre-periphery of organizational relationships. Hirst and 
Humphreys are attentive to the constitutive and disorientating effects of space in both locales, allowing micro-descriptions to sit suggestively and awkwardly on a stage of illdisciplined totality. They also supplement their descriptions with images of the two sites, thus in a literal sense providing the reader/viewer with a hybrid site/sight.

It is "in vain that we say what we see; what we say never resides in what we see" as Foucault so profoundly demonstrates in The Order of Things (1970: 10). In an exemplary essay on the constitutive blindness of organized knowledge, Connellan (2013) looks at the colour white as both figurative and a technology unto itself, as it functions to racialize and control organizational action in flatly deniable ways, specifically through appearing as utterly inconspicuous. By highlighting the politics of spaces that normalize whiteness as the absence of identity, the lack of anything remarkable, she is encouraging organization studies to pay heed to a very specific kind of white space: the bland spaces of mundaneity that form much of our organizational experience and yet informs little to none of organization studies. By highlighting a politics of sameness, an over-organizing of the everyday if you will, Connellan is questioning whether white spaces exist only in the terra incognita or whether they in fact are far more prevalent than we give them credit for; potentially even forming the basic architecture of organizing. Here the notion of new sites/sights shows itself as a distinct critique of organization studies, but not in the manner of, say, a critical management studies. Rather than seeing this as a resolutely political critique, we can find in Connellan's paper the germination of a more fundamental questioning of what organization studies have been up to for all these years.

As already mentioned, our desire to talk of new sites/sights is not mere wordplay. The notion of a new site implies the existence of something resolutely novel, something never before seen and therefore inherently interesting. However, the notion of a new sight can be understood in a more optical manner, as the discovery of a new way of seeing, and thus as potentially showing us something new in the assumedly old and well-known. A new site/sight can thus be both a call for more research into a newly discovered place, something that should stimulate every ambitious researcher into action, and as memento mori for the existing structure of a field. By shifting the sight onto the site we can show absences, lack, lacunae. Connellan does so by highlighting the role of the seen unseen, exhorting us to keep a shifting gaze.

In our final paper Rippin (2013) presents a telling of the manner in which the creation of knowledge artefacts within organization studies may point to a white space at the very heart of the field. By drawing on John Dewey's philosophy regarding art and experience, as well 
as her own long history of studying and engaging with The Body Shop, Rippin presents an argument for what she calls 'studio-based' investigations into the life-organizational, chiding the field for not paying enough heed to works of art as a way of expressing one's engagement with a phenomenon. Pointing out that the act of writing out a discourse on organizational life is a rather lifeless, reductionist and unfailingly limited way of engaging with the lived experience of organizing, she shows how the main white space of organization studies might lie in its own practices. We, as organizational scholars, study an organization in depth (or, at least we claim we do). After this, we seem more than happy to reduce this study to a mere text, often written in stilted and bloodless prose, and we then have the temerity to call this process - of making the organization less interesting than it is 'research'. Rippin challenges this in a subtle meditation on how her work with The Body Shop has changed through her use of arts-based methods, a practice that leads her to consider what this says about our capacity to reflect on organizations. This paper lends substance to our earlier musing on methodology suggesting that hybrid, even shape-shifting, ways of knowing may be vital to revealing new sights/sites (see Ellingson, 2009). Why, in the end, does it always come down to black markings on a white background?

\section{Conclusions: Towards the White Spaces}

The papers in this volume thus report from/on various white spaces in organization and introduce us to things that might represent contemporary versions of those 'fabulous beasts' that Pliny projected into the white spaces of known cartography. The dream of international travel, voices from the past, buildings that 'speak', the ghosts of children (see also Kenny, 2013), the Body Shop as a multi-panelled textile quilt, the psychic life of the colour white; these can all be read as hybrid fact-fictions - somewhere between reality and a fantasy world being constructed and made real in organization today. They are not perhaps powerful realities but they speak of a subaltern multiplicity or a new and uncharted 'cosmopolitics' (Stengers, 2010) in organization studies that is disruptive of dominant ontology. Some of these 'fabulous beasts' are disturbing, others are enlivening; yet, they all help to open up an extended realm of organization marked by complex socio-material relations and as such form the necessary joints and segments of a form of story-telling relevant to us today. The practical act of their creation reminds us that organization is constitutively in movement. Rather than an object of disinterested social scientific study we need to think-ourselvestowards-movement. In so doing we can seek an outside beyond the checkerboard of existing paradigmatic divides and the established positions and divisions of 'western' political representation. We are thereby enjoined to see and produce organization in hitherto unknown ways. Indeed, perhaps this movement is precursor to the saving of that which we value about North American and Western European modes of organization, confronted as 
we are with the ascendency of China and India, bringing with it the rise and evolution of alternative value and belief systems (cf. Latour, 2012).

It is interesting to note that none of these papers seek to ally themselves with established schools or genres of research in the field, either by theoretical/discursive fidelity or methodological fetishism. They are truly inter-disciplinary in the sense that they are well versed in developments in political theory, sociology, geography, art and architectural theory. All of the papers also reflect a willingness to experiment with methodology but in ways that avoid a return to the preoccupation and anxiety of academic subjectivity and identity that may have been inspired by that movement captured and advanced in Clifford and Marcus (1986). In so doing they grasp the benefits of what has been called elsewhere a 'postreflexive' methodology as it has been advanced in the wider social sciences (Maurer, 2005; Riles, 2011). Recognizing the inevitable epistemological dilemmas associated with knowledge practices, this post-reflexive turn works with the idea that a lot of academic research is studying practices and people much like ourselves who are partly involved in knowledge practices in which we (the academics) are the object of their analysis. No longer the epistemological privilege of the researcher, we must recognize this reflexivity amongst our informants and research subjects. More than this, it is important to remind ourselves that our research often involves academics studying other academics. It is perhaps best to see this then as a form of world-analysing that is also world-making but one that betrays the strange and complex circulation that exists between practitioner and researcher in which there may ultimately be no divide between the subject and object of research. An awareness of the circulation prompts us to consider that if advanced organizational theory is being first developed and applied by non-academic practitioners then organizing can no longer be thought of as an object of social scientific study. Instead we end up studying theory-aspractice as the divide between an empirical object and theoretical subject is no longer tenable. What is organizing? We are organizing.

Beyond this relocation of the object of organization, our proposal shifts the focus of analysis to the where and how of organizing in ways that seek to cut across what is still a rather static division of the discipline offered by that kind of meta-analysis that follows in the vein of Burrell and Morgan (cf. Hassard, 1993; Hassard and Wolfrom-Cox, 2013; Hatch and Cunliffe, 2006). In so doing we avoid the aggrandising theoretical building work that seeks dialectical synthesis across the 'gridlock' (Willmott, 1993), whilst also guarding against the dangers of supporting isolationism and paradigm incommensurability (Burrell, 1996; Jackson and Carter, 1993). It is perhaps not without some irony that these trends in organization 
analysis associated with radical humanist, symbolic and post-structural theory tend to reproduce in their representations of the discipline the dominant conventions of management practice with its two-dimensional boxes and two-by-two grids. If the basic ontological and epistemological oppositions used to make the divisions in organization studies are specious, then any efforts to resolve or synthesise what are ultimately phantom starting points will presumably end up in an even more specious space (see Latour, 2005).

This issue, then, should be seen as part of an emerging effort in organization studies to avoid the problem of resolving the established dichotomies in organization studies and the allied divisions of structure/agent or macro/micro that underpin the modern human and social sciences. Whilst all the papers in it take a highly discrete and specific object or problem for analysis - with implications for our understanding of history, race, space, experience, and international mobility, for example - they also implicitly work with broader intellectual developments in the social sciences. These papers are all intensively preoccupied with the ways in which realities get made and un-made through the properties of organization, a large part of which involves the co-implicated practices of social scientific research. These 'properties' are understood not in terms of abstract theoretical or technical variables, nor as simply the 'what', 'where', and 'when' of some prior 'concrete reality'. Neither simply realist nor constructivist as the discipline has been this issue works within a space that acknowledges its own practical and reflexive participation in the ongoing achievement of organization. For all of us organization is happening in the blind spots and aporias of our discipline. Even this very formulation tends to make static that which is essentially in movement, complexly temporal and spatialising. That we as researchers are also made up of these 'blind spots' as much as the world of organization taken as an object of analysis poses a considerable challenge to our routine academic practices.

\section{References}

Agamben, G. (2005). State of exception. University of Chicago Press. Chicago IL.

Ashcraft, K. L. (2001). 'Organized dissonance: Feminist bureaucracy as hybrid organization'. Academy of Management Journal, 44, 1301-1322.

Augé, M. (1995). Non-places: Introduction to an anthropology of supermodernity. London: Verso.

Badiou, A. 2005. Infinite Thought. London: Continuum.

Ballard, J.G. 2003. Millenium People. London: Norton. 
Banerjee S.B. (2011), 'Voices of the governed: Towards a theory of the translocal', Organization, 18(3), p.323-344

Bergson, H. (1911). Creative evolution. New York: H. Holt and Company.

Beverungen, A., Bohm, S. and Land, C. 2012. 'The Poverty of Journal Publishing', Organization,19(6): 929-938.

Böhm, S., Misoczky, M. C., \& Moog, S. (2012). ‘Greening capitalism? A Marxist critique of carbon markets'. Organization Studies, 33(11), 1617-1638.

Bolaño, R. (2008). 2666, trans. N. Wimmer, New York: Farrar, Straus and Giroux.

Booth, C. (2002). "Maps and Chaps": Metaphors of Traveling, Mapping and Surveying in Burrell and Morgan's (1979) Sociological Paradigms and Organisational Analysis'. Paper presented to the Critical Management Studies Workshop, Denver, CO.

Boltanski, L.\& Chiapello, È (2005) The New Spirit of Capitalism. London-New York: Verso.

Burrell, G. 1996. 'Normal Science, Paradigms, Metaphors, Discourses and Genealogies of Analysis.' In S. R. Clegg \& C. Hardy \& W. R. Nord (Eds.), Handbook of Organization Studies: 642-658. London: Sage.

Burrell, G. \& Morgan, G. 1979. Sociological Paradigms and Organisational Analysis. London: Heinemann.

Castells, M. (1996). The Rise of the Network Society, Volume I of The Information Age: Economy, Society and Culture. Massachusetts: Blackwell Publishing.

Chia, R. C. (1996). Organizational analysis as deconstructive practice Berlin: de Gruyter.

Clegg, S. R. (2006). 'Why is organization theory so ignorant? The neglect of total institutions'. Journal of Management Inquiry, 15(4), 426-430.

Clegg, S. R., \& Courpasson, D. (2007). 'The end of history and the futures of power'. Twenty-First Century Society, 2(2), 131-154.

Clegg, S. R., Courpasson, D., \& Phillips, N. X. (2006). Power and organizations. Pine Forge Press.

Cockerham, G., \& Cockerham, W. (2010). Health and globalization. Cambridge: Polity.

Coetzee, J. M. 1988. White Writing: On the Culture of Letters in South Africa. Johannesburg: Radix.

Cooper, R. (1983) 'The Other: A Model of Human Structuring', in Morgan, G. (1983). Beyond method: Strategies for social research. Sage Publications, Incorporated.

Cooper, Robert (1998) 'Assemblage notes' in Organized worlds. R. Chia (ed.), 131-180. London: Routledge.

Cooper, R. (2005). 'Peripheral Vision: Relationality'. Organization Studies, 26(11), 16891710. 
Cosgrove, D. E. (2008). Geography and vision: seeing, imagining and representing the world (Vol. 12). London: IB Tauris.

Crampton, J. W. (2009). Mapping: A critical introduction to cartography and GIS. WileyBlackwell.

Cunliffe, A. L. (2011). 'Crafting Qualitative Research Morgan and Smircich 30 Years On'. Organizational Research Methods, 14(4): 647-673.

Debord, G. (1958) 'Théorie de la dérive', Internationale Situationniste \#2, Paris.

De Cock, C., Cutcher, L., \& Grant, D. 2012. 'Finance Capitalism's Perpetually Extinguished Pasts: Exploring Discursive Shifts 2007-2011'. Culture and Organization, 18(2): 8588.

De Cock, C. \& Sharp, R. J. 2007. 'Process theory and research: Exploring the dialectic tension'. Scandinavian Journal of Management, 23(3): 233-250.

Dale, K. (2005). 'Building a social materiality: spatial and embodied politics in organizational control'. Organization, 12(5), 649-678.

Deleuze, G., \& Guattari, F. (1988). A Thousand Plateaus, trans. B. Massumi. London: Continuum.

Derrida, J. (1994). Specters of Marx, trans. Peggy Kamuf. London and New York: Routledge.

Giddens, A. 1990. The Consequences of Modernity. Cambridge: Polity.

Elden, S. (2009). Terror and territory: The spatial extent of sovereignty. Minneapolis \& London: U of Minnesota Press

Ellingson, L. (2009). Engaging Crystallization in Qualitative Research. Los Angeles: Sage.

Ferree, M. M., \& Martin, P. Y. (Eds.). (1995). Feminist organizations: Harvest of the new women's movement. Philadelphia: Temple University Press.

Foucault, M. (1970). The Order of Things. New York: Vintage.

Foucault, M. (1980) Power/Knowledge: Selected Interviews and Other Writings 1972-1977. New York, NY: Pantheon Books.

Foucault, M. (2003) Society Must Be Defended: Lectures at the Collège de France 19751976, translated by D. Macey (New York: Picador).

Foucault, M. (2008). The Birth of Biopolitics: Lectures at the College de France 1978-1979, trans. Graham Burchell. Houndmills, Basingstoke \& New York: Palgrave.

Giddens, A. (1990). The consequences of modernity. Stanford, Calif: Stanford University Press.

Graeber, D. (2013). The Democracy Project: A History, a Crisis, a Movement. Random House Digital, Inc.

Graham, S. (2010). Cities under siege: The new military urbanism. London: Verso. 
Hacking, I. (1990). The Taming of Chance. Cambridge. Eng.: Cambridge University Press.

Han, S. (2008). Navigating technomedia: caught in the Web. Lanham, Md: Rowman \& Littlefield.

Hassard, J. (1993). Sociology and organization theory: Positivism, paradigms, and postmodernity. Cambridge: Cambridge University Press.

Hassard, J. \& Wolfram-Cox (2013) 'Can Burrell and Morgan Still Inform Organization Theory? A Paradigm Framework for Post-paradigm Times', Organization Studies (forthcoming).

Hatch, M. J., \& Cunliffe, A. L. (2006). Organization theory: Modern, symbolic, and postmodern perspectives. Oxford: Oxford University Press.

Hatch, M. J., \& Yanow, D. (2008). 'Methodology by metaphor: Ways of seeing in painting and research'. Organization Studies, 29(1): 23-44.

Hobsbawm, E. 2011. How to Change the World: Marx and Marxism 1840-2011. London: Little, Brown.

Jackson, N., \& Carter, P. (1991). 'In defence of paradigm incommensurability'. Organization Studies, 12(1), 109-127.

Jackson, N. \& Carter, P. 1993. 'Paradigm Wars'. Organization Studies, 14: 721-725.

Jameson, F. 2009. Afterword. In S. Ross (Ed.), Modernism and Theory: A Critical Debate: 247-251. Oxford: Routledge.

Kaprow, A. (1965). Assemblages, environments, happenings. New York, N.Y: Abrams.

Kara, S. (2009). Sex trafficking: Inside the business of modern slavery. Columbia University Press.

Keenan, B. (1993). An evil cradling. London: Random House.

Kenny, K. (2013) 'Affective Disruption: Walter Benjamin and the 'history' of Ireland's Industrial Schools', Management and Organizational History 8(1):10-22.

Knox, H., Savage, M., \& Harvey, P. (2006). 'Social networks and the study of relations: networks as method, metaphor and form'. Economy and Society, 35(1), 113-140.

Latour, B. 2005. Reassembling the social: An introduction to actor-network theory. Oxford: OUP.

Latour B. (2012) Enquête sur les modes d'existence. Une anthropologie des Modernes, Paris: La Découverte.

Law, J. (Ed.) (1991). A sociology of monsters: essays on power, technology and domination (Vol. 171). London: Routledge.

Leahy, T., Bowden, V., \& Threadgold, S. 2010. 'Stumbling towards collapse: coming to terms with the climate crisis'. Environmental Politics, 19(6): 851-868. 
Levin, D. M. (1988). The Opening of Vision: Nihilism and the post-modern vision. New York and London: Routledge.

Linstead, S. A., Maréchal, G., \& Griffin, R. W. (forthcoming). Special Issue on "The Dark Side of Organization". Organization Studies.

Lynch, M. (2000). 'Against Reflexivity as an Academic Virtue and Source of Privileged Knowledge'. Theory, Culture \& Society, 17, 3, 26-54.

March, J. G. (2007). 'The study of organizations and organizing since 1945'. Organization Studies, 28(1), 9-19

Maurer, B. (2005). Mutual life, limited: Islamic banking, alternative currencies, lateral reason. Princeton, N.J: Princeton University Press.

Mitchell, T. (2011). Carbon democracy: political power in the age of oil. London: Verso Books.

Morgan, G. (1983). Beyond method: Strategies for social research. London: SAGE.

Morgan, G., Campbell, J., Crouch, C., Pedersen, O.K. and Whitley, R. 2010. The Oxford Handbook of Comparative Institutional Analysis. Oxford: Oxford University Press.

Morgan, G., Froud, J., Quack, S., \& Schneiberg, M. (2011). 'Capitalism in Crisis: Organizational Perspectives'. Organization, 18(2), 147-152.

Murray, C. (2005). 'Mapping Terra Incognita'. Polar Record, 41(217), 103-112.

Nietzsche, F. (1961). Thus spoke Zarathustra, trans. RJ Hollingdale. Harmondsworth: Penguin.

O'Doherty, D. P. (2008). 'The blur sensation: Shadows of the future'. Organization, 15(4), 535-561.

Parker, M. (2011). Alternative business: outlaws, crime and culture. London: Routledge.

Pinder, D. (2005). 'Arts of urban exploration'. Cultural geographies, 12(4), 383-411.

Prichard, C. \& Mir, R. 2010. 'Organizing Value'. Organization, 17(5): 507-515.

Rehn, A. 2008. 'On Meta-Ideology and Moralization - Prolegomena To a Critique of Management Studies'. Organization, 15(4): 598-609.

Riles, A. (2011). Collateral knowledge: Legal reasoning in the global financial markets. Chicago: University of Chicago Press.

Rose, N., \& Miller, P. (1992). 'Political power beyond the state: problematics of government'. British journal of sociology, 173-205.

Sadler, S. (1999). The situationist city. Cambridge, MASS: MIT press.

Saviano, R. 2008. Gomorrah. New York: Picador.

Scarry, E. (1985). The Body in Pain: The Making and Unmaking of the World. New York: University of Oxford Press. 
Stengers, I. (2010). Cosmopolitics. Minneapolis: University of Minnesota Press.

Stohl, R., \& Grillot, S. (2009). The international arms trade (Vol. 7). Cambridge: Polity.

Strathern, M. 2002. 'Abstraction and Decontextualization: An Anthropological Comment', in S. Woolgar (Ed.), Virtual Society? Technology, Cyberbole, Reality: 302-313. Oxford: Oxford University Press.

Taussig, M. (1993). Mimesis and Alterity. A Particular Study of the Senses. London \& New York: Routledge.

Thanem, T. (2011) The Monstrous Organization. Cheltenham: Edward Elgar.

Turkle, S. (1995). Life on the screen: Identity in the age of the Internet. New York: Simon \& Schuster.

Ulmer, G. L. (1985). Applied grammatology: post (e)-pedagogy from Jacques Derrida to Joseph Beuys. Baltimore: Johns Hopkins University Press.

Watt, P. \& Zepeda, R. (2012) Drug War Mexico: Politics, Neoliberalism and Violence in the New Narcoeconomy. London \& New York: Zed Books.

Weick, K. E. (1979). The psychology of organization. Reading: Addison-Wesley.

Willmott, H. 1993. 'Breaking the Paradigm Mentality'. Organization Studies, 14(5): 681-719.

Wood, D., \& Fels, J. (2008). The natures of maps: Cartographic constructions of the natural world. Chicago: University of Chicago Press.

\section{NOTES}

${ }^{i}$ It is an insulation our field has been all too happy to indulge in of course. Prichard and Mir $(2010,509)$, for example, document how in the context of the global financial crisis "key gatherings of the critically-inclined management and organization studies community" (at the EGOS, Critical Management Studies, and Academy of Management conferences) failed to pay much attention to "the major economic events of the day and the changing character of organized economic relations".

ii Rather than obsessing about epochal avant-gardes we might alternatively take inspiration from Roberto Bolaño (2008) and think of organization studies as a 'vast forest'. Using this metaphor to describe literature Bolaño suggests that, "Literature doesn't consist solely of masterpieces, but rather is populated by so-called minor works... Literature is a vast forest and the masterpieces are the lakes, the towering trees or strange trees, the lovely, eloquent 
flowers, the hidden caves, but a forest is also made up of ordinary trees, patches of grass, puddles, clinging vines, mushrooms, and little wildflowers (p.785)".

iii There is voluminous literature studying the virtues and dangers of the network metaphor encompassing work from Castells (1996) in political geography, Boltanski and Chiapello (2005) in political sociology, and Strathern (2002) in anthropology. This literature and its interlocutory secondary debates are too vast to cite in a reasonable limit. What we note is the persistent confusion in this literature mixing up Castells's networks metaphor, social network analysis, and actor-network theory (see Knox et al., 2006). Dale's paper (2005) is promising, however, opening up a possible form of organizational analysis outside the opposition of networks and hierarchies.

iv We are not the first to identify the power of maps and cartography as a silent, but underlying influence on the organization of our discipline (see Booth, 2002, for example). 